\title{
Inactivation of Glucose Oxidase by the Cationic Detergent, Hexadecyltrimethylammonium Bromide
}

\author{
Haruhito Tsuge, Masami Suzuki, Nahoko Kito, \\ Yuji NaKanishi, Kazuji OHashi \\ and Koichiro AOKI* \\ Department of Agricultural Chemistry and \\ *Department of Synthetic Chemistry, Gifu University, \\ 1-1, Yanagido, Gifu 501-11, Japan
}

Received December 27, 1982

\begin{abstract}
Glucose oxidase (EC 1.1.3.4) was inactivated almost completely at $\mathrm{pH} 7.0(0.1 \mathrm{~m}$ sodium phosphate buffer, ionic strength $=0.22$ ) by the cationic detergent, hexadecyltrimethylammonium bromide at a molar ratio of $\mathrm{HTAB} / \mathrm{GOD} \geqq 1,700$. This inactivation was accompanied by 1 ) a blue shift in the region of $270 \sim 300 \mathrm{~nm}, 2)$ an increase in FAD fluorescence at $520 \mathrm{~nm}$, and 3) an approximately 3-fold increase in tryptophan fluorescence at $340 \mathrm{~nm}$. The extent of inactivation of glucose oxidase by the cationic detergent was different from that observed with other detergents under the same experimental conditions. When the substrate, D-glucose, was added to the enzyme solution before the addition of hexadecyltrimethylammonium bromide under anaerobic conditions, the activity of glucose oxidase decreased to $70 \%$ of its original value after incubation at $25^{\circ} \mathrm{C}$ for $24 \mathrm{hr}$. In contrast, an anionic detergent, sodium dodecylsulfate, or a nonionic detergent, Triton X100 , did not produce measurable changes in the enzyme activity.

Thus, the inactivation of glucose oxidase by the cationic detergent is caused by the formation of an ion-pair between a cationic head group of the detergent and anionic amino acid residues of the enzyme.
\end{abstract}

Glucose oxidase ( $\beta$-D-glucose: oxygen 1oxidoreductase, EC 1.1.3.4) has been well characterized as a glyco- and FAD-containing flavoprotein. ${ }^{1 ~ 7)}$ This enzyme consists of two homogeneous subunits ${ }^{6)}$. with stable conformation, although only a small amount of ordered structure has been reported. ${ }^{7,8)}$

It is well known that the apparent activity and the tertiary structure of this enzyme do not change when the enzyme is dissolved in a solution of the anionic detergent, $\mathrm{SDS},{ }^{2,4)}$ i.e., the enzyme retains its full activity at $\mathrm{pH} 5.5$ even after a $30-\mathrm{hr}$ incubation in $1 \%$ SDS solution at $30^{\circ} \mathrm{C}$. To be denatured, this enzyme must undergo considerably more vigorous treatment. ${ }^{6)}$

The effect of a cationic detergent on glucose oxidase had never been examined. The in- teraction of glucose oxidase with HTAB was studied kinetically, spectrophotometrically, fluorophotometrically and by analyzing the binding isotherm after changing the molar ratio of $\mathrm{HTAB} / \mathrm{GOD}$. It was found that glucose oxidase from Aspergillus niger is greatly affected by HTAB. At $\mathrm{pH} 7,25^{\circ} \mathrm{C}$ and at a molar ratio of $\mathrm{HTAB} / \mathrm{GOD} \geqq 1,700$, the coenzyme FAD is released, and the tryptophan fluorescence is increased.

\section{MATERIALS AND METHODS}

Chemicals. Glucose oxidase (from A. niger, Type II) was purchased from sigma (St. Louis, MO, U.S.A.) and purified as described earlier. ${ }^{6)}$ However, it was decided that it was unnecessary to carry out one of the DEAE-cellulose column procedures in order to obtain an electrophoretically pure enzyme preparation since the enzyme obtained

Abbreviations: SDS, sodium dodecylsulfate; HTAB, hexadecyltrimethylammonium bromide; GOD, glucose oxidase; UV, ultraviolet; $I$, ionic strength; Trp, tryptophan. 
from the supplier was a more purified form than had been available previously. HTAB was synthesized according to the published procedure, ${ }^{9)}$ and hexadecyltrimethylammonium chloride and dodecyltrimethylammonium bromide were purchased from Tokyo Kasei (Tokyo, Japan). Orange II was obtained from E. Merck (Darmstadt, Germany).

Chemicals for activity measurements were the same as those used for a previous report, ${ }^{10}$ ) except for $o$ dianisidine, ${ }^{*}$ which was purchased from sigma and crystallized twice from $50 \%$ hot ethanol.

Other chemicals used were commercially available reagents.

Equipment. UV and visible spectra were recorded using an Hitachi Model UV 200-10 double beam spectrophotometer with a $1-\mathrm{cm}$ cuvette. Fluorescence excitation and emission spectra were recorded with an Hitachi Model MPF-3 fluorescence recording spectrophotometer at $25^{\circ} \mathrm{C}$. Routine measurements of absorbance and fluorescence intensity were made using an Hitachi Model 101 spectrophotometer and Model 203 fluorescence spectrophotometer equipped with a Xenon lamp, respectively.

Method of inactivation. Unless otherwise noted, the total ionic stregth of the buffer was maintained at a constant value $(I=0.22)$, which was calculated by the equation described by Segel. ${ }^{11)}$ Glucose oxidase $(0.6 \mu \mathrm{M})$ and HTAB (usually $0.5 \mathrm{~mm}$ ) were allowed to react in $0.1 \mathrm{M}$ sodium phosphate buffer ( $\mathrm{pH} 7.0$ ), $0.4 \mathrm{M}$ sodium acetate buffer ( $\mathrm{pH} 4.0$ ), or $0.25 \mathrm{M}$ sodium acetate buffer $\left(\mathrm{pH} \mathrm{5.6)}\right.$ at $25^{\circ} \mathrm{C}$ for $24 \mathrm{hr}$ in a brown test tube.

Equilibrium dialysis. To determine the binding isotherm, $5 \mathrm{ml}$ of $3.6 \mu \mathrm{M}$ glucose oxidase was dialyzed against $25 \mathrm{ml}$ of the detergent solution at 5 or $25^{\circ} \mathrm{C}$ for $72 \mathrm{hr}$. The concentrations of HTAB, both free and bound, were determined spectrophotometrically using Orange II in accordance with the procedure reported by Hiramatsu et al. ${ }^{12)}$

Enzyme assay. The activity of glucose oxidase was assayed as described earlier, ${ }^{10)}$ after suitable dilution of the sample with $0.05 \mathrm{M}$ potassium phosphate buffer $(\mathrm{pH} 7.0)$. The activity was expressed most conveniently as the increased absorbance of oxidized $o$-dianisidine at $400 \mathrm{~nm}$ for a 10 min-reaction period. The enzyme preparation used had a normalized specific activity ${ }^{2)}$ of more than $65 \mu \mathrm{mol}$ $\mathrm{O}_{2}$ consumed per min per mg protein in the presence of catalase at $\mathrm{pH} 7.0$ and $25^{\circ} \mathrm{C}$.

Measurement of protein concentration. Protein concentration was determined by use of the relation, $A_{280}^{0.1 \%}=1.54$. Our previously reported value was erroneous, ${ }^{6)}$ and has been corrected. The molecular weight of glucose oxidase was taken as 160,000 daltons. $^{6}$

\section{RESULTS}

\section{Effects of $p H$ and ionic strength on the in-} teraction between glucose oxidase and HTAB Solutions of glucose oxidase at $\mathrm{pH} 7.0$ and of $\mathrm{HTAB} / \mathrm{GOD}$ at molar ratios of 170,830 and 1,670 were incubated at $25^{\circ} \mathrm{C}$ for $24 \mathrm{hr}$, after which the enzyme activity was determined. As shown in Fig. 1(A), the activity loss was rather rapid, and obeyed first-order kinetics, at least during the initial 4 hours regardless of the molar ratio HTAB/GOD. The deviation of the measured activity from a straight line, seen after that 4 -hr period, suggested that the inactivation proceeded in at least two steps. Rogers and Brandt ${ }^{13)}$ found that halide ions inhibited glucose oxidase competitively at certain $\mathrm{pH}$ values. Presumably, this is the reason that the activity at zero-time does not intersect the ordinate at $100 \%$. Glucose oxidase became somewhat unstable under anaerobic conditions. However, when the substrate, D-glucose $(25 \mathrm{~mm})$, and a large excess of HTAB were added, in this order, to the solution containing glucose oxidase and incubated for $6 \mathrm{hr}$ under anaerobic conditions, the enzyme activity remained at $70 \%$ of its original value (Fig. 1(B)).

The solution of glucose oxidase became turbid upon addition of HTAB. Such turbidity, which made the photometric measurements difficult, was also noted by Hiramatsu et al. ${ }^{12)}$ Solutions containing $0.6 \mu \mathrm{M}$ glucose oxidase and HTAB (molar ratio $\mathrm{HTAB} / \mathrm{GOD}=$ 830) at $\mathrm{pH} 7.0$, but, at various ionic strengths, were prepared and incubated for $1 \mathrm{hr}$ at $25^{\circ} \mathrm{C}$. When the turbidity of these mixtures was monitored by determining their absorbance at $540 \mathrm{~nm}$, the bell-shaped curve shown in Fig. 2 was obtained. Maximum absorbance was observed at $0.03 \mathrm{M}(I=0.06)$, and there was no apparent turbidity above $0.06 \mathrm{M}(I>0.13)$. Enzyme activity decreased gradually with the increase in the ionic strength of the medium. In the region where there was no apparent tur- 


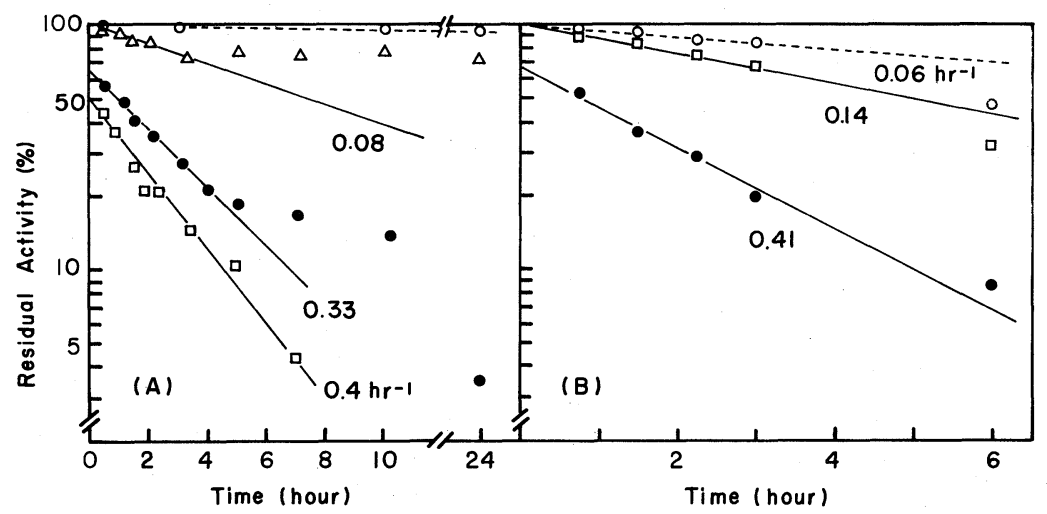

FIG. 1. Effect of HTAB on the Inactivation of Glucose Oxidase $(0.6 \mu \mathrm{M})$ in $0.1 \mathrm{M}$ Sodium Phosphate Buffer (pH 7.0, $I=0.22$ ).

(A) Glucose oxidase was incubated in the presence of various concentrations of $\mathrm{HTAB}$ at $25^{\circ} \mathrm{C}$. Molar ratios of HTAB/GOD were: $0(\bigcirc) ; 167(\triangle) ; 830(\bigcirc) ; 1,670(\square)$ (B) Glucose oxidase was placed in the main chamber of a Tunberg-type tube, and HTAB, at a molar ratio HTAB/GOD $=830$, and with or without $25 \mathrm{mM}$ D-glucose, was in the side chamber. After repeated evacuation and flushing with $\mathrm{N}_{2}$, these two solutions were mixed, and the resulting mixture was then incubated at $25^{\circ} \mathrm{C}$. Glucose oxidase without $\mathrm{HTAB}(\bigcirc)$; reaction mixtures having molar ratios of $\mathrm{HTAB} / \mathrm{GOD}=830$ with $(\square)$ and without $(\bigcirc) 25 \mathrm{~mm}$ D-glucose. The numerals are the first-order rate constants $\left(\mathrm{hr}^{-1}\right)$ for glucose oxidase inactivation.

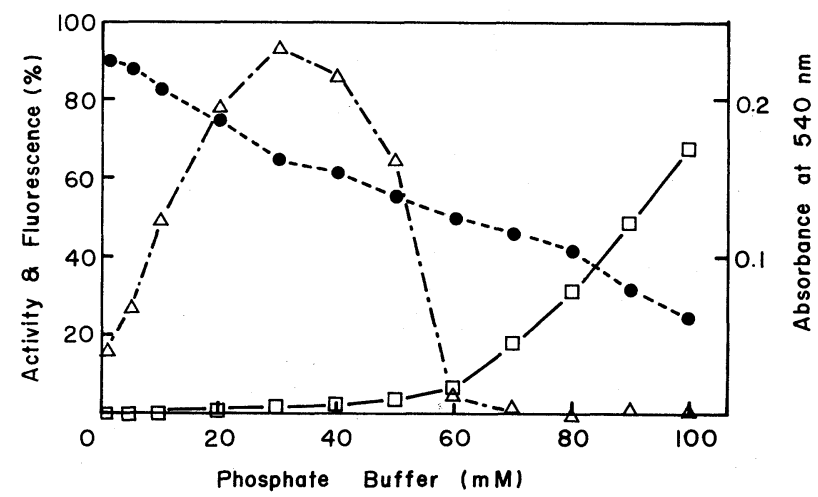

FIG. 2. Effect of Phosphate Buffer Concentration (pH 7.0) on Some Properties of a Solution Containing $0.6 \mu \mathrm{M}$ Glucose Oxidase and HTAB at a Constant Molar Ratio of HTAB/GOD $=830$.

Glucose oxidase was incubated with various ionic strengths of phosphate buffer at $25^{\circ} \mathrm{C}$ for $1 \mathrm{hr}$. The parameters measured were: turbidity in terms of absorbance at $540 \mathrm{~nm}(\boldsymbol{\Delta})$; glucose oxidase activity $(\boldsymbol{O})$; FAD fluorescence intensity at $520 \mathrm{~nm}$ when excited at $365 \mathrm{~nm}(\square)$.

bidity $(I>0.13)$, a characteristic increase in the intensity of FAD fluorescence at $520 \mathrm{~nm}$ was noted, although the values obtained at concentrations lower than $I=0.13$ might contain some ambiguity. In the region of lower ionic strength $(I<0.13)$, the turbidity remained unchanged, even after a 24-hr incubation. On the contrary, in the higher ionic strength region $(I>0.13)$, turbidity appeared soon after the addition of HTAB, and disappeared over a 3- hr incubation.

Loss of glucose oxidase activity was also caused by a change in $\mathrm{pH}$. Figure 3 illustrates typical changes of enzyme activity and of the intensities of FAD and tryptophan fluorescence at pH's 7.0 and 4.9 , as functions of the molar ratio of $\mathrm{HTAB} / \mathrm{GOD}$. When $0.6 \mu \mathrm{M}$ glucose oxidase was incubated at $\mathrm{pH} 7.0$ and at an $\mathrm{HTAB} / \mathrm{GOD}=830$, a remarkable loss of activity was observed; this was accompanied 


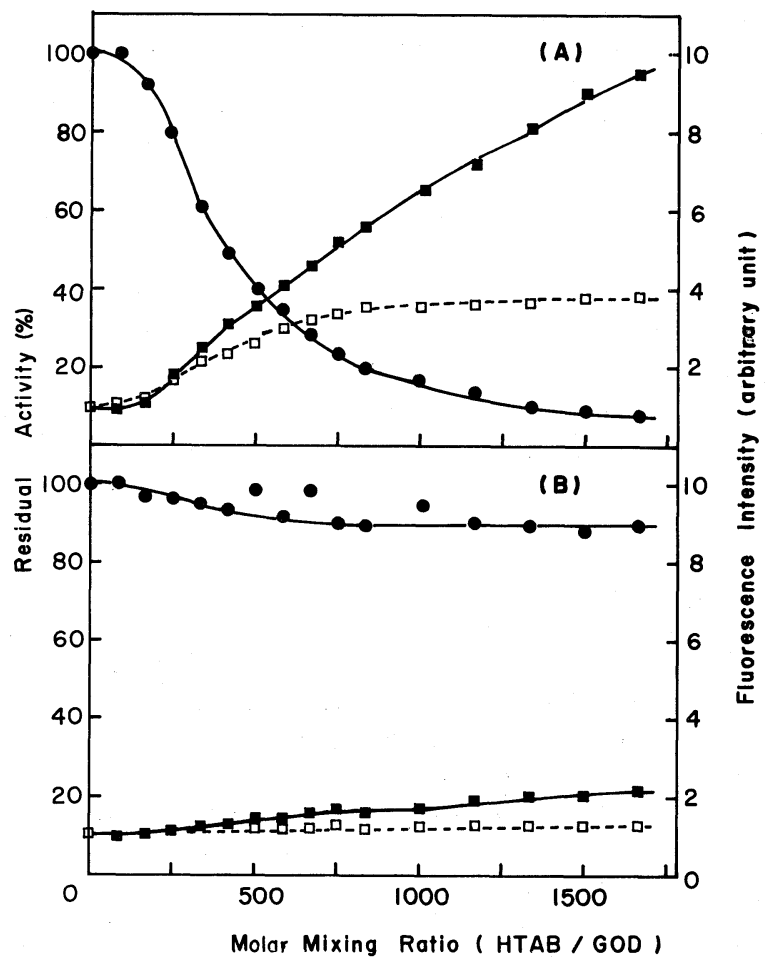

FIG. 3. Effect of the Molar Ratio HTAB/GOD on the Activity of Glucose Oxidase $(0.6 \mu \mathrm{M})$ and on the Fluorescence Intensities.

Glucose oxidase was incubated at $25^{\circ} \mathrm{C}$ for $24 \mathrm{hr}$ with varying amounts of HTAB in a mixture of either: (A), $0.1 \mathrm{M}$ sodium phosphate buffer ( $\mathrm{pH} 7.0, I=0.22)$, or $(\mathrm{B}), 0.4 \mathrm{M}$ sodium acetate buffer $(\mathrm{pH} 4.9, I=0.22)$. The parameters measured were: glucose oxidase activity $(\mathbf{O})$; FAD fluorescence intensity at $520 \mathrm{~nm}$ when excited at $365 \mathrm{~nm}(\square)$; tryptophan fluorescence intensity at $340 \mathrm{~nm}$ when excited at $295 \mathrm{~nm}(\square)$.

by an increase in the intensities of FAD and tryptophan fluorescence. However, the activity loss was negligible at $\mathrm{pH} 4.9$ and also at $\mathrm{pH}$ 5.6.

Effect of HTAB on enzyme activity and tryptophan fluorescence

Various amounts of HTAB were added to different concentrations of glucose oxidase $(0.12,0.6$ or $3 \mu \mathrm{M})$ in $0.1 \mathrm{~m}$ sodium phosphate buffer ( $\mathrm{pH} 7.0)$. These solutions were incubated at $25^{\circ} \mathrm{C}$ for $24 \mathrm{hr}$, before the enzyme activities, as well as the tryptophan fluorescence at $340 \mathrm{~nm}$ (excitation wavelength, $295 \mathrm{~nm}$ ) were determined. The values obtained were plotted versus the molar ratio of HTAB/GOD (Fig. 4 (A)). Activity loss was a function of both enzyme and HTAB concentrations. At enzyme level of 0.6 or $3.0 \mu \mathrm{M}$ there occurred an almost complete loss of activity at or near an HTAB/GOD of 500 . When the enzyme concentration was $0.12 \mu \mathrm{M}$, $65 \%$ of the activity remained at the same molar ratio.

The correlation between remaining activity and increased tryptophan fluorescence was virtually unity $(\gamma=0.99)$, regardless of enzyme concentration, as shown in Fig. 4 (B).

At $\mathrm{pH} 7.0$ it was found that the FAD fluorescence continued to increase in intensity with an increase in the molar ratio of HTAB/GOD from zero to 1,700 . Since the fluorescence intensity of $1.2 \mu \mathrm{M}$ authentic FAD at the same $\mathrm{pH}$ was enhanced more than 2-fold at a molar ratio of $\mathrm{HTAB} / \mathrm{GOD}=830$, it was concluded that this enhancement was due, in part, to the FAD itself. (Note: $0.6 \mu \mathrm{M}$ glucose oxidase corresponds to $1.2 \mu \mathrm{M}$ FAD since there 

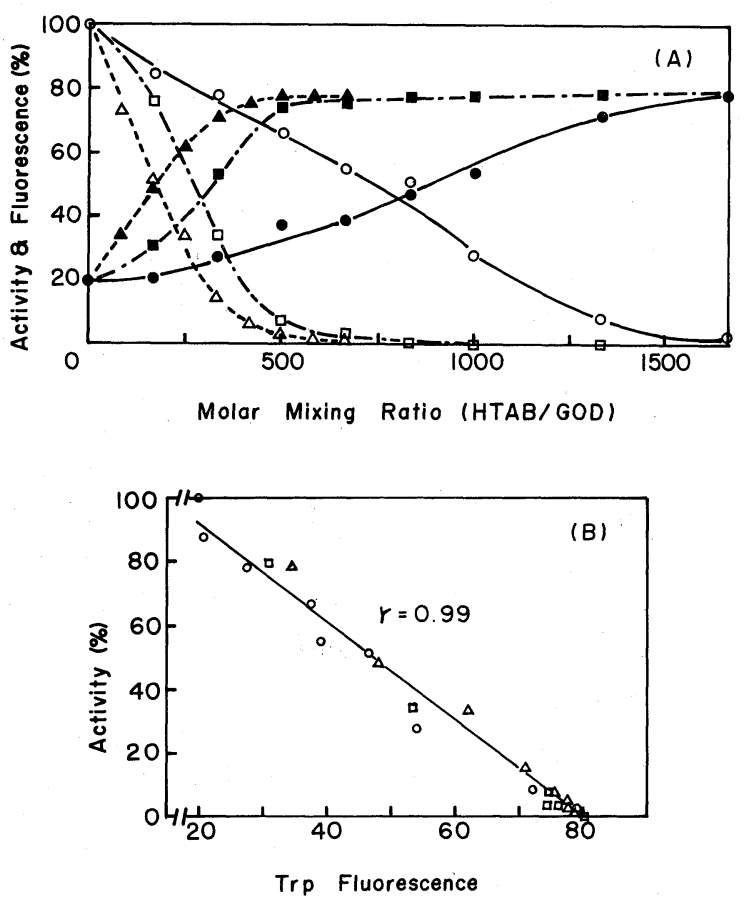

FIG. 4. Changes of Glucose Oxidase Activity and Tryptophan Fluorescence as Functions of the Molar Ratio HTAB/GOD.

(A) Effects of the molar ratio HTAB/GOD on the activity (open symbols) and on the tryptophan fluorescence at $340 \mathrm{~nm}$ when excited at $295 \mathrm{~nm}$ (closed symbols). Concentrations of glucose oxidase were: $0.12 \mu \mathrm{M},(\bigcirc, \bigcirc)$; $0.6 \mu \mathrm{M},(\square, \boldsymbol{\square}) ; 3.0 \mu \mathrm{M},(\triangle, \boldsymbol{\Delta})$. (B) Correlation between activity and tryptophan fluorescence $(\gamma=0.99)$. Concentrations of glucose oxidase were: $0.12 \mu \mathrm{M},(\bigcirc) ; 0.6 \mu \mathrm{M},(\square) ; 3.0 \mu \mathrm{M},(\triangle)$.

are $2 \mathrm{~mol}$ of FAD per enzyme molecule: ${ }^{1 \sim 7)}$ )

\section{Spectrophotometric measurements of inacti-} vated glucose oxidase

When the solution containing $0.6 \mu \mathrm{M}$ glucose oxidase and HTAB (molar ratio $\mathrm{HTAB} / \mathrm{GOD}=830$ ) in $0.1 \mathrm{M}$ sodium phosphate buffer ( $\mathrm{pH} 7.0$ ) was incubated for $24 \mathrm{hr}$, an activity loss of approximately $90 \%$ occurred. The absorption and fluorescence spectra were measured at suitable intervals during the incubation period. In Fig. 5 (A) are shown the difference spectra, in the visible range, of glucose oxidase plus HTAB versus glucose oxidase and of FAD plus HTAB versus FAD for the 24-hr incubation. As already reported, ${ }^{6}$ native glucose oxidase gives three peaks, characteristic of typical flavoproteins, at 278, 383 and $454 \mathrm{~nm}$. When the enzyme is incubated in the presence of HTAB, a hypsochromic shift occurs in both the first and the second tran- sition peaks. However, the change in the first peak, seen in Fig. 5(A), should be attributed to the disruption of intermolecular bonding between FAD and apoprotein, ${ }^{14)}$ since only the second transition peak, near $370 \mathrm{~nm}$, shifted hypochromically to the blue side when HTAB was added to the solution containing authentic FAD.

As shown in Fig. 5(B), the difference spectra of the UV absorption of glucose oxidase plus HTAB versus glucose oxidase for the given incubation periods gave rise to positive peaks at 257 and around $320 \mathrm{~nm}$, and a broad negative peak between $270 \sim 300 \mathrm{~nm}$. The negative peak became more pronounced with prolonged incubation times. Such a peak has often been observed when the protein is denatured by usual denaturants, such as, urea or guanidine hydrochloride. ${ }^{15}$ ) Therefore, it was suggested that the formation of this peak results from the exposure of the aromatic 
(A)
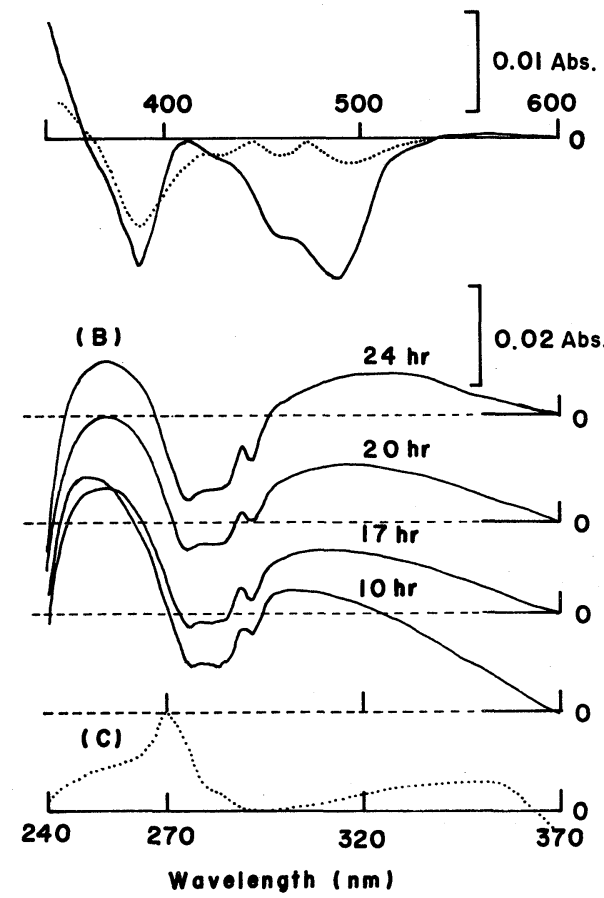

FIG. 5. Determination of the Difference Spectra of Glucose Oxidase, Inactivated under Different Reaction Parameters.

Glucose oxidase $(0.6 \mu \mathrm{M})$ or FAD $(1.2 \mu \mathrm{M})$ was incubated at $25^{\circ} \mathrm{C}$ in $0.1 \mathrm{M}$ sodium phosphate buffer $(\mathrm{pH} 7.0, I=0.22)$ alone or together with HTAB, at a molar ratio of HTAB/ GOD of 830 or 410 . (A) The visible difference spectra of GOD + HTAB vs. GOD (solid line) and of FAD + HTAB vs. FAD (dotted line) after 24-hr incubations. (B) Time-dependent changes observed in the UV difference spectra of GOD+HTAB vs. GOD measured at given times. (C) The UV difference spectrum of FAD + HTAB vs. FAD after a 24-hr incubation.

amino acid residues of the protein to the solvent. Free FAD did not give a sufficient negative peak in this region, but did show a large positive peak at $270 \mathrm{~nm}$ (Fig. 5(C)). Thus, this latter spectral change should be attributed to the influence of HTAB on the FAD.

\section{Fluorescence measurement}

Both the fluorescence excitation spectrum and emission spectra of the tryptophan residue in glucose oxidase are shown in Fig. 6(A). The shape of the emission spectrum is essentially the same, with an emission peak shift of only $3 \sim 4 \mathrm{~nm}$ to the longer wavelength, even when the molar ratio of $\mathrm{HTAB} / \mathrm{GOD}$ equals 1,670 , while the intensity of the tryptophan fluorescence is enhanced by about 3-fold with increased amounts of HTAB. The intensity of the tryptophan fluorescence in a solution containing $13 \mu \mathrm{M}$ L-tryptophan and $1 \mathrm{~mm}$ HTAB, whose molar ratio of 76 for HTAB/Trp was equivalent to that of a glucose oxidasecontaining solution having an HTAB/GOD of $\left.830,{ }^{6}\right)$ was essentially the same as that observed for L-tryptophan alone. The fluorescence maximum was still close to $350 \mathrm{~nm}$ (data not shown).

The FAD molecule in glucose oxidase is really nonfluorescent, ${ }^{2,16)}$ and consequently, it is impossible to estimate the degree of fluorescence polarization of FAD in the bound state. After glucose oxidase was incubated at $\mathrm{pH} 7.0$ and at $25^{\circ} \mathrm{C}$ for $24 \mathrm{hr}$ with different concentrations of HTAB, the fluorescence intensity of FAD measured at $520 \mathrm{~nm}$ increased remarkably (Fig. 6(B)). This seems to indicate that FAD was released from the apoprotein, since the degree of fluorescence polarization of such a solution, having a molar ratio of 830 for $\mathrm{HTAB} / \mathrm{GOD}$, was 0.031 . This value agrees well with that for free FAD reported by Weber. ${ }^{17)}$

\section{Binding isotherm of the glucose oxidase-HTAB system}

To estimate the number of HTAB molecules bound to glucose oxidase, a solution of the two at $\mathrm{pH} 7.0(I=0.22)$ was dialyzed at either $5^{\circ} \mathrm{C}$ or $25^{\circ} \mathrm{C}$ until equilibrum was achieved. The concentration of the enzyme was $3.6 \mu \mathrm{M}$, and that of the HTAB was below the critical micelle concentration $(\sim 1 \mathrm{mM}) .{ }^{18)}$ The number of HTAB molecules bound per molecule of the enzyme is shown as a function of the concentration of free detergent in solution (Fig. 7).

The binding isotherm at $5^{\circ} \mathrm{C}$ consisted of two parts: one, a curve having a gentle slope and termed the statistical binding region, and the other, a curve with a steep slope and termed the cooperative binding region. When 


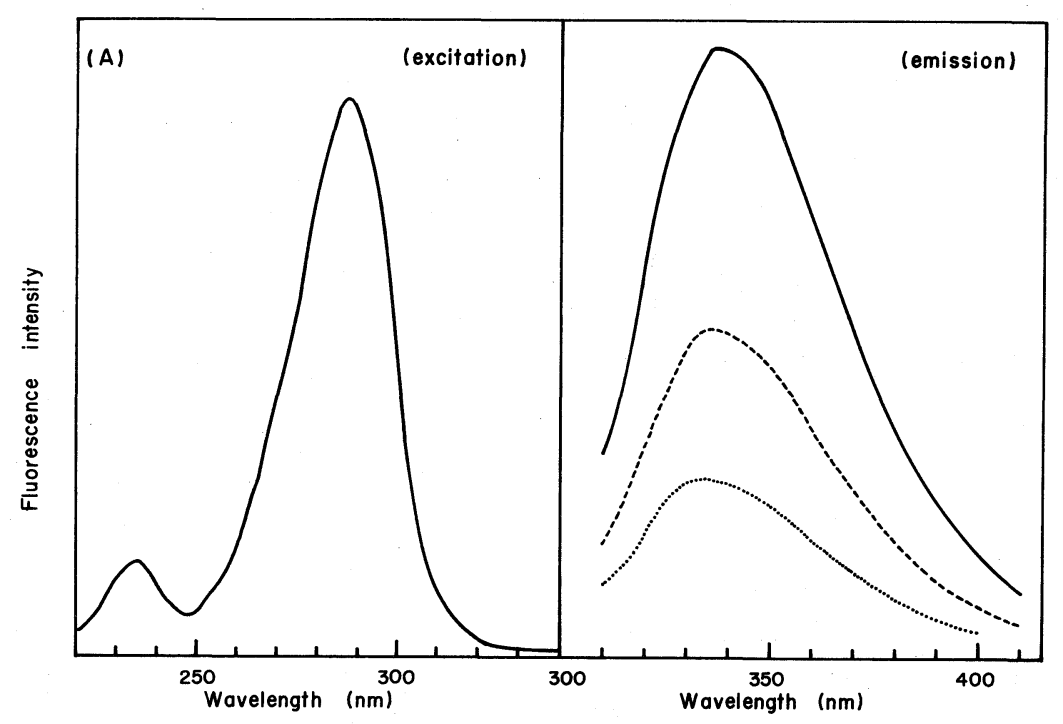

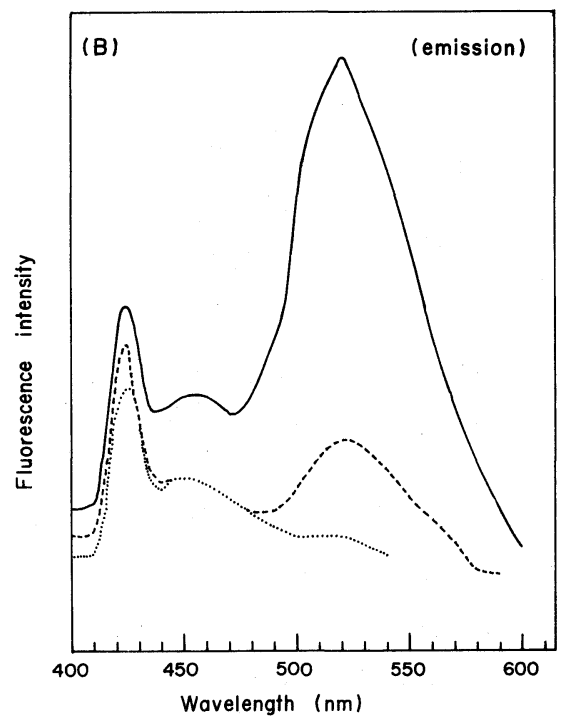

FIG. 6. Fluorescence Spectra of a Glucose Oxidase Solution Containing HTAB.

Glucose oxidase $(0.6 \mu \mathrm{M})$ containing HTAB at a given molar ratio $\mathrm{HTAB} / \mathrm{GOD}$ was incubated in $0.1 \mathrm{M}$ sodium phosphate buffer (pH 7.0, I=0.22) for $24 \mathrm{hr}$ at $25^{\circ} \mathrm{C}$. (A) Excitation spectrum of tryptophan fluorescence emitted at $340 \mathrm{~nm}$ (left) and the emission spectra excited at $300 \mathrm{~nm}$ (right). (B) FAD fluorescence emission spectra excited at $370 \mathrm{~nm}$. Molar ratios of HTAB/GOD were: 0, (------); 330, (----); 1,670, (-).

the temperature was raised to $25^{\circ} \mathrm{C}$, the binding isotherm shifted to the left, indicating that the binding was endothermic. In addition, the binding isotherm at $25^{\circ} \mathrm{C}$ seemed to have no

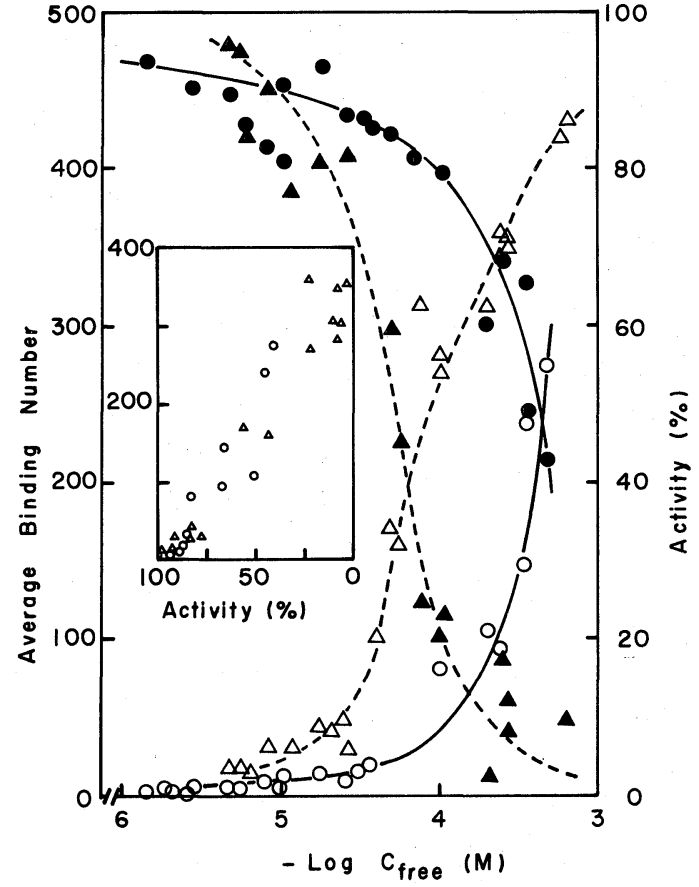

FIG. 7. The Number of HTAB Molecules Bound to Glucose Oxidase, and Change in Enzyme Activity as a Function of the Concentration of Free HTAB $\left(C_{\text {free }}\right)$.

All the measurements were made in $0.1 \mathrm{M}$ sodium phosphate buffer ( $\mathrm{pH} 7.0, I=0.22$ ). Other details are given under Materials AND Methods. The binding isotherm $(\triangle, \bigcirc)$ and enzyme activity $(\boldsymbol{\Delta}, \boldsymbol{O})$ were measured both at $5^{\circ} \mathrm{C}$ (solid line) and at $25^{\circ} \mathrm{C}$ (dotted line). (Inset) Correlation of the average number of HTAB molecules bound $v s$. residual activity at $5^{\circ} \mathrm{C}(\bigcirc)$ and at $25^{\circ} \mathrm{C}(\triangle)$. Some data in the statistical binding region were omitted. 
statistical binding region. This result was probably due to the limited sensitivity of the analytical method for detergents. The binding isotherm at $5^{\circ} \mathrm{C}$ was analyzed by the Scatchard equation, ${ }^{19)}$ and the maximum number of sites of statistical binding was estimated to be 8 .

There was no loss of activity observed in the statistical binding region, while in the cooperative binding region, a loss of enzyme activity occurred at $5^{\circ} \mathrm{C}$, as well as at $25^{\circ} \mathrm{C}$ (Fig. 7 , inset).

\section{Effect of other detergents}

Interactions between glucose oxidase and SDS, as well as Triton X-100 were studied to obtain additional information on the binding behavior of HTAB to glucose oxidase. Concentration of enzyme and detergent and the molar ratios of detergent/GOD were the same as those used in the HTAB study. Experiments were made at pH's 4.9, 5.6 and 7.0, where glucose oxidase was active. ${ }^{3)}$ The results obtained are summarized in Table I. No significant loss of activity nor enhancement of FAD fluorescence was observed in any anionic or nonionic detergent solution. Tryptophan fluorescence did not change in the SDS solution and could not be measured in Triton X-100, since the Triton X-100 itself emitted a rather strong interfering fluorescence at the same wavelength. The fact that the presence of SDS did not alter the original activity of glucose oxidase at the three pH's tested agreed well with the results obtained by other investigators. ${ }^{2,5)}$

To find out whether a substitute for the counter-ion in the hexadecyltrimethylammonium salt would alter the extent of inactivation or spectrophotometric properties of the enzyme-detergent solution, the HTAB studies were repeated using the chloride salt of the detergent instead of the bromide one. Hexadecyltrimethylammonium chloride inactivated glucose oxidase at a somewhat lower concentration than HTAB. However, other spectrophotometric properties tested gave almost the same results using both salts. Dodecyltrimethylammonium bromide showed
Table I. EfFect of Detergents on the INACTIVATION OF GLUCOSE OXIDASE

Glucose oxidase $(0.6 \mu \mathrm{M})$ was incubated at a constant ionic strength $(I=0.22)$ with a detergent at a molar ratio of detergent/GOD of 830 . The incubation was carried out at different $\mathrm{pH}$ 's for 24-hr periods.

\begin{tabular}{|c|c|c|c|c|}
\hline Detergent $^{a}$ & $\begin{array}{l}\text { Head } \\
\text { group }\end{array}$ & $\begin{array}{c}\text { Counter } \\
\text { ion }\end{array}$ & $\mathrm{pH}$ & $\begin{array}{c}\text { Remaining } \\
\text { activity } \\
(\%)\end{array}$ \\
\hline \multirow[t]{3}{*}{ НТАВ } & \multirow[t]{3}{*}{+} & \multirow[t]{3}{*}{$\mathrm{Br}^{-}$} & $4.9^{b}$ & $\sim 80$ \\
\hline & & & $5.6^{c}$ & $\sim 75$ \\
\hline & & & $7.0^{d}$ & $10 \sim 15$ \\
\hline HTAC & + & $\mathrm{Cl}^{-}$ & $7.0^{d}$ & $>5$ \\
\hline DTAB & + & $\mathrm{Br}^{-}$ & $7.0^{d}$ & 50 \\
\hline \multirow[t]{3}{*}{ SDS } & \multirow[t]{3}{*}{-} & \multirow[t]{3}{*}{$\mathrm{Na}^{+}$} & $4.9^{b}$ & 90 \\
\hline & & & $5.6^{c}$ & 95 \\
\hline & & & $7.0^{d}$ & 95 \\
\hline \multirow[t]{2}{*}{ Triton X-100 } & \multirow[t]{2}{*}{ None } & \multirow[t]{2}{*}{-} & $4.9^{b}$ & 97 \\
\hline & & & $7.0^{d}$ & 95 \\
\hline
\end{tabular}

a Abbreviations: HTAB, hexadecyltrimethylammonium bromide; HTAC, hexadecyltrimethylammonium chloride; DTAB, dodecyltrimethylammonium bromide; SDS, sodium dodecylsulfate.

$b \quad 0.4 \mathrm{M}$ sodium acetate buffer.

c $0.25 \mathrm{M}$ sodium acetate buffer.

d $0.1 \mathrm{M}$ sodium phosphate buffer.

some ability to inactivate the enzyme, although the potency was inferior to that of HTAB.

\section{DISCUSSION}

The interaction of proteins with detergents has been studied using various techniques for more than three decades. ${ }^{9,12,18,20 \sim 33)}$ There are vast amounts of data, especially concerning bovine plasma albumin-anionic detergent and bovine plasma albumin-cationic detergent systems. ${ }^{9,12,21 \sim 23,25,33)}$ Generally, the shape of the binding isotherm of a protein-detergent system $^{12,20)}$ is similar to that given in Fig. 7. The binding is statistical in the lower concentration of detergent, and is cooperative in the higher concentration region. ${ }^{20)}$ It is believed that the ionic detergent binds to the protein by both electrostatic and hydrophobic bonds in the statistical binding region. ${ }^{18,21,27)}$ On the contrary, however, detergents bind to the unfolded protein in such a way as to form a 
micelle cluster in the cooperative binding region.

This same mechanism may be applied to the present system of glucose oxidase and HTAB. In the statistical binding region, the number of specific binding sites was approximately 8 , and there was no loss of activity. In this binding region, the electrostatic interaction occurs between the cationic head group of HTAB and the anionic amino acid residues of the enzyme, and the hydrophobic interaction occurs between the hydrocarbon tail of the detergent and the hydrophobic patch of the enzyme. $^{21,27 \sim 29)}$ In the cooperative binding region, the activity was lost almost completely by unfolding of the enzyme and/or formation of a micelle cluster on the enzyme molecule.

Glucose oxidase lost its activity rather easily in the presence of HTAB at $\mathrm{pH}$ 7. This is in contrast to the fact that the enzyme has been found to be quite stable in SDS solution. ${ }^{2,4,6)}$ The stability of glucose oxidase in an SDS solution having a molar ratio for SDS/GOD of 830 was confirmed at three $\mathrm{pH}$ 's through the experiment.

This instability in the presence of HTAB is the result of essential differences between HTAB and SDS in the signs of the charges of the head groups and in the lengths of the hydrocarbon chains. However, the latter is not a major cause of the difference in the extent of inactivation, since dodecyltrimethylammonium bromide also inactivated the enzyme under comparable conditions (see Table I).

A plausible mode for the denaturation of the enzyme in question by HTAB is the formation of an ion-pair between the protein and the detergent. If one considers that 1) the extent of the enzyme inactivation depends upon the $\mathrm{pH}$ and ionic strength of the medium, and 2) some number of anionic amino acid residues are exposed on the protein surface at $\mathrm{pH} 7$, since the isoelectric point of the enzyme is $4.2,{ }^{3)}$ then the denaturation of glucose oxidase could not occur without taking electrostatic interaction into account.

Abnormally high SDS bindings have been observed for the hydrophobic fragment of cytochrome $b_{5}$ from liver microsomal membranes $^{30)}$ and for the major glycoprotein from erythrocyte membranes. ${ }^{31)}$ The mode of association of SDS with these proteins has been found to follow a course of co-micellization between the hydrophobic portion of the protein and the preformed detergent micelles. However, the mode of association of HTAB with glucose oxidase seems to be different from this mechanism, since 1) cooperative binding occurred at a lower concentration than the critical micelle concentration, ${ }^{18)}$ and 2) the HTAB concentration necessary for the denaturation of the enzyme changed and was dependent upon the enzyme concentration used (see Fig. 3). If the preformed micelle of HTAB was responsible for the co-micellization with native glucose oxidase, the HTAB concentration needed to denature the enzyme should be constant.

According to the proposal of Bright and Gibson regarding the catalysis of glucose oxidase, the enzymatic reaction occurs as a result of a general base abstraction of $\mathrm{C}-1$ bound hydrogen. ${ }^{34)}$ Weibel and Bright ${ }^{35}$ have proposed two interesting hypotheses concerning the oxidation of the substrate, $\beta$-D-glucose, by this enzyme. In either hypothesis, the substrate must first be attacked by the carboxylate anion in order for the proton abstraction from the $\mathrm{C}-1$ position to occur. Such an idea has recently been supported by the work of Porter and Bright. ${ }^{36)}$ The finding that $\mathrm{D}$-glucose can protect the enzyme against denaturation would lend substance to the proposal that some of the 8 anionic amino acid residues of the enzyme might be located at the active site.

The increase in FAD fluorescence of solutions having HTAB/GOD molar ratios greater than 830 can be predicted for two reasons: one, the release of coenzyme FAD from the apoprotein, and, the other, the destruction of intramolecular complexes between the isoalloxazine and adenine moieties. ${ }^{37)}$ It is well known that free FAD fluorescences poorly $(\sim 15 \%$ of FMN) in the aqueous solution because the tight interaction between isoalloxa- 
zine and adenine moieties. ${ }^{38)}$ When HTAB was added to the free FAD solution, the FAD fluorescence at $520 \mathrm{~nm}$ increased approximately 2-fold. Thus, this observation supports the idea that native glucose oxidase first releases its coenzyme, whose intramolecular complex is then destroyed upon reaction with HTAB.

Acknowledgments. This investigation was supported in part by a Grant-in-Aid for Scientific Research from the Ministry of Education, Science and Culture of Japan. Thanks are due to Dr. M. Sogami and Dr. S. Nagaoka, of the Faculty of Medicine of Gifu University, for their measurement of the fluorescence spectra. We are also indebted to Dr. K. Hiramatsu, from the Faculty of Engineering, for his generous gift of HTAB and valuable suggestions during this experiment.

\section{REFERENCES}

1) J. H. Pazur, K. Kleppe and A. Cepure, Arch. Biochem. Biophys., 111, 351 (1965).

2) B. E. P. Swoboda and V. Massey, J. Biol. Chem., 240, 2209 (1965).

3) J. H. Pazur, "Methods in Enzymology," Vol. 9, ed. by W. A. Wood, Academic Press, New York, N. Y., 1966, p. 82.

4) S. Nakamura and S. Fujiki, J. Biochem., 63, 51 (1968).

5) S. Nakamura and S. Hayashi, FEBS Lett., 41, 327 (1974).

6) H. Tsuge, O. Natsuaki and K. Ohashi, J. Biochem., 78, 835 (1975)

7) H. J. Bright and D. J. T. Porter, "The Enzymes," Vol. 12, ed. by P. D. Boyer, Academic Press, New York, N. Y., 1975, p. 421.

8) B. Jirgensons, J. Biol. Chem., 240, 1064 (1965).

9) K. Aoki and K. Hiramatsu, Anal. Biochem., 60, 213 (1974).

10) H. Tsuge and H. Mitsuda, J. Biochem., 73, 199 (1973).

11) I. H. Segel, "Biochemical Calculations," 2nd Ed., John Wiley and Sons, New York, N. Y., 1976, p. 66.

12) K. Hiramatsu, C. Ueda, K. Iwata, K. Arikawa and K. Aoki, Bull. Chem. Soc. Jpn., 50, 363 (1977).

13) M. J. Rogers and K. G. Brandt, Biochemistry, 10, 4630 (1971).

14) W. R. Weimar and A. H. Neims, "Riboflavin," ed. by R. B. Revlin, Plenum Press, New York, N. Y., 1975, p. 1.

15) H. A. Scheraga, "Protein Structure," Academic
Press, New York, N. Y., 1961, p. 217.

16) H. Tsuge and H. Mitsuda, J. Vitaminol., 17, 24 (1971).

17) G. Weber, "Flavins and Flavoproteins," ed. by E. C. Slater, Elsevier, Amsterdam, The Netherlands, 1966, p. 15 .

18) Y. Nozaki, J. A. Reynolds and C. Tanford, J. Biol. Chem., 249, 4452 (1974).

19) G. Scatchard, J. S. Coleman and A. L. Shen, J. Am. Chem. Soc., 79, 12 (1957).

20) J. A. Reynolds, "Methods in Enzymology," Vol. 61, ed. by C. H. W. Hirs and S. N. Timasheff, Academic Press, New York, N. Y., 1979, p. 58.

21) W. Kauzmann, "Advances in Protein Chemistry," Vol. 14, ed. by C. B. Anfinsen, M. L. Anson, K. Bailey and J. T. Edsall, Academic Press, New York, N. Y., 1959, p. 1.

22) F. W. Putnam and H. Neurath, J. Biol. Chem., 150, 263 (1943).

23) J. F. Foster and K. Aoki, J. Amer. Chem. Soc., 80, 5215 (1958).

24) M. L. Meyer and W. Kauzmann, Arch. Biochem. Biophys., 99, 348 (1962).

25) R. V. Decker and J. F. Foster, Biochemistry, 5, 202 (1966).

26) J. Steinhardt, J. G. Leidy and J. P. Mooney, Biochemistry, 11, 1809 (1972).

27) M. N. Jones, H. A. Skinner, E. Tipping and A. Wilkinson, Biochem. J., 135, 231 (1973).

28) M. N. Jones, H. A. Skinner and E. Tipping, Biochem. J., 147, 229 (1975).

29) A. Ushiwata, K. Nakaya and Y. Nakamura, Biochim. Biophys. Acta, 395, 215 (1975).

30) N. C. Robinson and C. Tanford, Biochemistry, 14, 369 (1975).

31) S. Grefrath and J. A. Reynolds, Proc. Natl. Acad. Sci. U.S.A., 71, 3913 (1975).

32) K. Nakaya, A. Ushiwata and Y. Nakamura, Biochim. Biophys. Acta, 439, 116 (1976).

33) K. Aoki, H. Okabayashi, S. Maezawa, T. Mizuno, M. Murata and K. Hiramatsu, Biochim. Biophys. Acta, 703, 11 (1982).

34) H. J. Bright and Q. H. Gibson, J. Biol. Chem., 242, 994 (1967).

35) M. K. Weibel and H. J. Bright, J. Biol. Chem., 246, 2734 (1971).

36) D. J. T. Porter and H. J. Bright, J. Biol. Chem., 252, 4361 (1977).

37) I. M. Gascoigne and G. K. Radda, J. Chem. Soc., Chem. Commun., 21, 522 (1965).

38) D. Voet and A. Rich, "Flavins and Flavoproteins," ed. by H. Kamin, University Park Press, Baltimore, MD, 1971, p. 23. 